CORRESPONDENCE

\section{Myths of exercise induced right ventricular injury: the bright side of the moon}

In their meta-analysis, the authors of the article $^{1}$ describe an injury of the right ventricle (RV) and cite in this context the increase in biomarkers as an indication for such an injury. This statement is not tenable. ${ }^{2}$ The increase in biomarkers can hardly be used as an argument for a right ventricular injury and often has a different meaning. $^{3} 4$

On the other hand, the authors fail to mention all the reports about a non-injury of the (RV) by a permanent load. ${ }^{5-7}$ In many serial examinations no pathological findings could be shown among elite athletes ${ }^{5}$ and in the case of endurance/marathon runners ${ }^{67}$ no chronic injury of the (RV) could be detected. Compared with sedentary ${ }^{6}$ or active $^{7}$ controls (leisure-time runners), ultraendurance runners showed similar RV global strain values ${ }^{6}$ and ventricular ectopy. ${ }^{7}$ An exercise induced isolated fibrosis of the RV (excepting after myocarditis) has not been well documented yet.

In the main studies cited by the authors, an exact documentation of the fluid uptake directly after and during the race has not been carried out. Because of the considerably higher survival rate of an endurance athlete compared to the general population the increase in biomarkers and the right ventricular injury by endurance sport should be interpreted with great caution, ${ }^{2}$ and should first be verified by prospective studies with exact documentation of fluid uptake, weight controls, body composition and calorie uptake before and after the race.

In their present form, the statements about a right ventricular injury by sport cannot be accepted ${ }^{2}$ - although they are, of course, open to discussion.

\section{Roman Leischik}

Correspondence to Priv Doz (PD), Dr med Roman Leischik, Department of Health, School of Medicine, University Witten/Herdecke, Elberfelder str. 1, Hagen, Nordrhein-Westfalen 58095, Germany; privat@dr-leischik.de Competing interests None.

Provenance and peer review Not commissioned; internally peer reviewed.

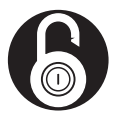

OPEN ACCESS
Open Access This is an Open Access article distributed in accordance with the Creative Commons Attribution Non Commercial (CC BY-NC 4.0) license, which permits others to distribute, remix, adapt, build upon this work non-commercially, and license their derivative works on different terms, provided the original work is properly cited and the use is non-commercial. See: http:// creativecommons.org/licenses/by-nc/4.0/

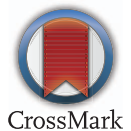

To cite Leischik R. Br J Sports Med 2015;49:1025.

Accepted 20 November 2014

Published Online First 19 December 2014

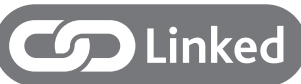

- http://dx.doi.org/10.1136/bjsports-2014-094441

Br J Sports Med 2015;49:1025.

doi:10.1136/bjsports-2014-094363

\section{REFERENCES}

1 Elliott AD, La Gerche A. The right ventricle following prolonged endurance exercise: are we overlooking the more important side of the heart? A meta-analysis. Br J Sports Med 2014;72:587-97.

2 Leischik R. Endurance sport and cardiac injury. Pol J Cardiol Kardiol Polska 2014;72:311-21.

3 Tanindi A, Cemri M. Troponin elevation in conditions other than acute coronary syndromes. Vasc Health Risk Manag 2011;7:597-603.

4 Wilson M, O'Hanlon R, Prasad S, et al. Biological markers of cardiac damage are not related to measures of cardiac systolic and diastolic function using cardiovascular magnetic resonance and echocardiography after an acute bout of prolonged endurance exercise. Br J Sports Med 2011;45: 780-4.

5 D'Andrea A, Riegler L, Golia E, et al. Range of right heart measurements in top-level athletes: the training impact. Int I Cardiol 2013;164:48-57.

6 Simsek Z, Tas MH, Gunay E, et al. Speckle-tracking echocardiographic imaging of the right ventricular systolic and diastolic parameters in chronic exercise. Int I Cardiovasc Imaging 2013;29:1265-71.

7 Rimensberger C, Carlen F, Brugger N, et al. Right ventricular adaptations and arrhythmias in amateur ultra-endurance athletes. Br J Sports Med 2013;48:1179-84. 